\title{
Analisis Kemampuan Panel Surya Monokristalin 150 Watt pada Arus dan Pengisian yang Dihasilkan
}

\author{
M. Barkah Salim ${ }^{1}$ dan Nurlaila Rajabiah ${ }^{2}$ \\ ${ }^{1}$ Fakultas Keguruan dan IImu Pendidikan Universitas Muhammadiyah Metro \\ ${ }^{2}$ Fakultas Teknik Universitas Muhammadiyah Metro \\ JL. KH Dewantara NO 116 Iringmulyo, Metro Timur \\ E-mail: barkah_um@yahoo.co.id
}

\begin{abstract}
Abstrak
Matahari merupakan sumber energi yang tidak akan bisa habis. Oleh karena itu, pemanfaatan energi matahari haruslah menjadi prioritas. Dengan banyaknya jenis panel surya yang telah dikembangkan, peneliti melakukan analisis jenis panel surya monokristalin 150 watt. Tujuan dari penelitian ini adalah untuk menganalisis besar arus dan tegangan yang dihasilkan panel surya pada beberapa keadaan langit yaitu mendung, cerah berawan, cerah. Metode penelitian yang dilakukan adalah eksperimen. Dari data yang sudah didapatkan bahwa energi yang dihasilkan oleh panel surya pada saat mendung berkisar 0,6-0,8 ampere, saat cerah berawan 0,9-1,9 ampere, dan saat cerah 2,0-3,2 ampere. Besar energi listrik yang mampu dihasilkan sebesar $8 \%$. Akan tetapi apabila keadaan cerah bisa menghasilkan dua kali lipatnya. Saran bagi pembaca adalah jika ingin melakukan pengambilan data pastikan panel surya benar-benar terkena sinar matahari selama pengambilan data dan di halaman terbuka. Jauh lebih baik lagi jika sudutnya disesuaikan dengan arah sinar matahari.
\end{abstract}

Kata kunci: Energi terbarukan, panel surya, dan metode eksperimen

\begin{abstract}
The sun is a source of energy that cannot be used up. Therefore, the utilization of solar energy must be a priority. With the many types of solar panels that have been developed, researchers conducted an analysis of 150 watt monocrystalline solar panels. The purpose of this study is to know the amount of current and voltage produced by solar panels in some conditions of the sky, namely cloudy, bright cloudy, and bright. The research method used was the experiment. From the data that has been obtained, it can be found that the energy produced by solar panels during cloudy ranges from 0.6-0.8 amperes, when it is cloudy, 0.9-1.9 amperes, and when bright 2.0-3.2 amperes. The amount of electrical energy that can be produced is $8 \%$. However, if the sunny state can produce twice that Suggestions for readers are if you want to take data to make sure the solar panels are completely exposed to the sun during data collection and in the open area. Much better if the angle is adjusted in the direction of sunlight.
\end{abstract}

Keywords: Renewable energy, solar panels, experiment method.

\section{PENDAHULUAN}

Energi matahari merupakan energi yang tidak akan bisa habis hingga datangnya hari kiamat. Sinar yang dihasilkan mampu berubah dari satu bentuk energi menjadi energi yang lain. Batas energi yang dihasilkan cahaya matahari pun tanpa batas. Akan tetapi, cahaya yang masuk ke bumi akan berkurang jika keadaan langit mendung atau terjadi hujan, dan rotasi bumi mengakibatkan terjadinya malam. Hal-hal tersebutlah yang mempengaruhi besar kecilnya energi cahaya matahari yang masuk ke bumi. Menurut Fonash (2010:2) pasokan energi untuk sel surya adalah foton yang berasal dari matahari. Masukan ini didistribusikan, dengan cara yang bergantung pada variabel seperti garis lintang, waktu, kondisi atmosfer, serta pada panjang gelombang yang berbeda.

Negara Indonesia merupakan negara yang dilalui oleh garis khatulistiwa. Artinya bahwa negara Indonesia merupakan negara yang selalu dilewati oleh matahari setiap harinya. 
Jika energi cahaya matahari tersebut tidak digunakan dengan sebaik-baiknya, maka Indonesia akan merugi.

Berdasarkan Perpres No 22 tahun 2017 tentang Rencana Umum Energi Nasional (RUEN) (Widodo,2017), pengembangan pasokan listrik dari mulai daerah hingga provinsi masih sangat jauh. Butuh penyadaran pada seluruh masyarakat tentang pemanfaatan energi surya sehingga masyarakat sadar dengan sendirinya untuk memanfaatkan energi surya.

Penelitian pemanfaatan energi matahari sudah banyak dilakukan oleh peneliti-peneliti baik dalam dan luar negeri. Hasil penelitian tersebut berharap dapat bermanfaat bagi kelangsungan hidup manusia untuk masa depan. Dengan mulai menipisnya energi fosil, maka penelitian-penelitian tentang energi terbarukan terus dilakukan. Salah satu bentuk hasil penelitian yang sudah mulai dirasakan adalah Panel Surya. Seperti penelitian yang telah dilakukan oleh Subandi dan Hani (2015) membahas tentang penggunaan panel surya 50watt sebagai energi penggerak pompa air. Dilakukan pula oleh Dzulfikar \& Broto (2016), membahas tentang optimalisasi pemanfaatan energi listrik tenaga surya skala rumah tangga. Oleh karena itu penting kiranya kita mengetahui kemampuan dari masing-masing panel surya.

Panel surya banyak macamnya, akan tetapi panel surya yang baik terbuat dari bahan silikon. Besarnya daya yang dihasilkan oleh panel surya beraneka ragam tergantung dari luas permukaan dari panel surya. Ada panel surya yang memiliki daya 10 Watt, 50 Watt, 100 Watt, 150 Watt, dll. Setiap daya memiliki karakteristik berbeda-beda dalam menghasilkan arus dan tegangan. Oleh sebab itu peneliti ingin mencoba menganalisis panel surya dengan daya 150 Watt. Panel surya yang peneliti gunakan adalah monokristalin karena dari beberapa artikel yang peneliti baca monokristalin sangan efisien pada keadaan langit cerah. Akan tetapi jika terjadi mendung akan mengalami drop energi cukup lumayan.

Tujuan dari penelitian ini adalah menganalisis kemampuan panel surya pada arus dan tegangan yang dihasilkan.

Prinsip kerja sel surya didasarkan pada efek fotovoltaik (Jager,dkk, 2014 : 23), yaitu generasi perbedaan potensial di persimpangan dua bahan yang berbeda dalam menanggapi radiasi elektromagnetik. Efek fotovoltaik terkait erat dengan efek fotolistrik, dimana elektron dipancarkan dari bahan yang telah menyerap cahaya dengan frekuensi di atas frekuensi ambang tergantung-materi. Pada tahun 1905, Albert Einstein memahami bahwa efek ini dapat dijelaskan dengan mengasumsikan bahwa cahaya terdiri dari quanta energi yang didefinisikan dengan baik, yang disebut foton. Energi seperti foton diberikan oleh

$$
E=h v
$$

di mana $h$ adalah konstanta Planck dan $v$ adalah frekuensi cahaya. Untuk penjelasannya tentang efek fotolistrik Einstein menerima Hadiah Nobel dalam Fisika pada tahun 1921.

Efek fotovoltaik dapat dibagi menjadi tiga proses dasar yaitu generasi pembawa muatan karena penyerapan foton dalam bahan yang membentuk persimpangan
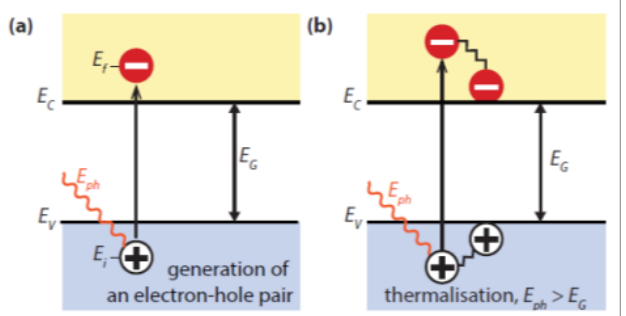

Gambar 1. (a) Menggambarkan penyerapan foton dalam semikonduktor dengan celah pita Eg. Foton dengan energi $E_{p h}=h v$ menggerakkan elektron dari Ei ke Ef. Pada Ei lubang dibuat. (b) Jika Eph> Eg, bagian dari energi mengalami thermalisasi.

Pemisahan selanjutnya dari operator muatan foto yang dihasilkan di persimpangan. Perhatikan gambar 2. (1) Penyerapan foton mengarah pada pembentukan pasangan elektron-lubang. (2) Biasanya, elektron dan lubang akan bergabung. (3) Dengan membran semipermeabel, elektron dan lubang dapat dipisahkan. (4) Elektron yang terpisah dapat digunakan untuk menggerakkan sirkuit listrik. (5) Setelah elektron melewati sirkuit, mereka akan bergabung kembali dengan lubang. 


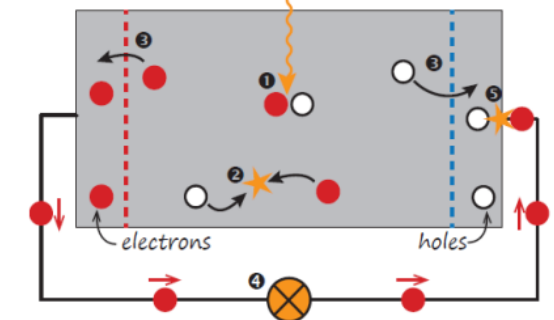

Gambar 2. Model sel surya dengan bentuk sederhana

Pembawa muatan diekstrak dari sel surya dengan kontak listrik sehingga mereka dapat melakukan pekerjaan di sirkuit eksternal (Gambar 2). Energi kimia dari pasangan elektron-lubang akhirnya diubah menjadi energi listrik. Setelah elektron melewati sirkuit, mereka akan bergabung kembali dengan lubang di antarmuka metalabsorber, seperti yang diilustrasikan pada Gambar 2.

Adapun macam-macam panel surya menurut UD rajawali Perkasa (2018) yaitu Monokristalin dan Polikristalin. Panel surya tipe monokristalin menggunakan material silikon sebagai bahan utama penyusun sel surya. Material silikon ini diiris tipis menggunakan teknologi khusus. Dengan digunakannya teknologi inilah, kepingan sel surya yang dihasilkan akan identik satu sama lainnya dan juga memiliki kinerja tinggi.

Tipe panel surya ini menggunakan sel surya jenis crystalline tunggal yang memiliki efisiensi yang tinggi. Secara fisik, tipe panel surya ini dapat dikenali dari warna sel hitam gelap dengan model terpotong pada tiap sudutnya.

Jenis panel surya Polikristalin terbuat dari beberapa batang kristal silikon yang dicairkan, setelah itu dituangkan dalam cetakan yang berbentuk persegi. Kristal silikon dalam jenis panel surya ini tidak semurni pada sel surya monocrystalline. Jadi, sel surya yang dihasilkan tidak identik antara satu sama lainnya. Efisiensinya pun lebih rendah dari monocrystalline.

Adapun hasil dari pemanfaatan dari panel surya yaitu Arsa (2017) melakukan memanfaatkan panel surya bagi pariwisata di Bali karena jauh dari PLN. Dari hasil yang telah ia lakukan, panel surya sangat cocok untuk melayani wilayah-wilayah terpencil di Indonesia atau yang masih jauh dari jangkauan PLN seperti halnya Villa-villa di Bali yang jauh dari pusat kelistrikan.
Dengan apa yang telah dilakukan Arsa, panel surya merupakan alat yang penting dalam menghasilkan energi. Layak jika energi yang dihasilkan oleh panel surya di analisis agar masyarakat tahun kemampuan dari masing-masing panel surya. Akan tetapi pada kegiatan kali ini peneliti hanya menganalisis panel surya 150 watt.

\section{METODE/EKSPERIMEN}

Metode penelitian yang akan dilakukan peneliti adalah eksperimen. Metode eksperimen yang digunakan karena peneliti melakukan langsung dan melakukan beberapa kali pengambilan data. Adapun indikatorindikator yang akan peneliti amati antara lain keadaan awan, besar arus yang dihasilkan, besarnya dan kenaikan daya tiap waktu. Tempat penelitian di rumah peneliti yaitu Perum Rindang Lestari Jalan Letjen Suprapto, Kelurahan Margorejo, Kecamatan Metro Selatan, Mulyojati, Metro Bar., Kota Metro, Lampung 34122. Peneliti melakukan penelitian di rumah pribadi karena rumah peneliti di daerah persawahan dan tidak ada pohon atau apa pun yang dapat menghalangi cahaya matahari masuk ke panel surya.

Adapun alat dan bahan yang digunakan yaitu, Panel surya 150 watt, inverter 300 watt, multimeter digital, regulator panel surya, jepit buaya, kabel PLN, aki kering 2 buah 12volt.

Data yang diperoleh berbentuk data kuantitatif dan diterjemahkan, atau dalam Bahasa lain deskriptif kuantitatif. Persamaan yang digunakan adalah persamaan regresi linier yaitu

$$
y=b x+a
$$

Alat bantu dalam menganalisis menggunakan software Exel untuk mempermudah dalam perhitungan.

Alat dan bahan digunakan seperti pada tabel 1 . Tabel 1. Alat dan Bahan

\begin{tabular}{lll}
\hline No & Alat & Bahan \\
\hline 1 & Multimeter digital & Panel Surya \\
2 & Capit Buaya & Kabel PLN \\
3 & Inverter & 2 buah Aki \\
& & kering 12V \\
4 & Charge Controler & \\
\hline
\end{tabular}

Bentuk rangkaian dari alat seperti pada gambar 3. 


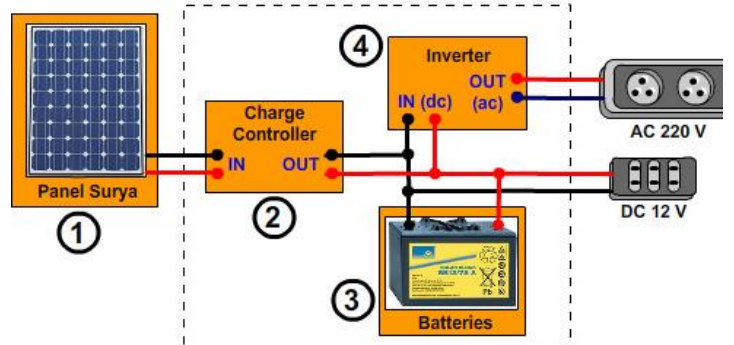

Gambar 3. Rangkaian alat panel surya

Prosedur percobaan pada penelitian ini antara lain :

1. Merangkaikan alat seperti pada gambar 3 .

2. Meletakkan panel surya di tanah lapang atau tempat yang terkena sinar matahari secara langsung

3. Mengamati display pada regulator panel surya. Pada display panel surya terdapat tampilan arus yang dihasilkan panel surya tiap waktunya.

4. Mencatat hasil pengamatan pada tabel 2 dan tabel 3.

Tabel 2. Keadaan langit

\begin{tabular}{lllc}
\hline No & Keadaan langit & \multicolumn{2}{c}{$\begin{array}{c}\text { Rentang Arus } \\
\text { yang dihasilkan } \\
\text { dari panel surya } \\
\text { (Amper) }\end{array}$} \\
\hline 1 & Mendung & $\ldots$ & $\ldots$ \\
2 & Cerah berawan & $\ldots$ & $\ldots$ \\
3 & Cerah & $\ldots$ & $\ldots$ \\
\hline
\end{tabular}

\begin{tabular}{cccccc}
\cline { 2 - 5 } & \multicolumn{5}{c}{ Tebel 3. Tabel Pengamatan } \\
\hline No & Arus & Jam & $\begin{array}{c}\text { Pengisian } \\
\text { Batrai }\end{array}$ & Cuaca & $\begin{array}{c}\text { Tegangan } \\
\text { aki (Volt) }\end{array}$ \\
\hline 1 & $\ldots$ & $\ldots$ & $\ldots$ & $\ldots$ & $\ldots$ \\
2 & $\ldots$ & $\ldots$ & $\ldots$ & $\ldots$ & $\ldots$ \\
3 & $\ldots$ & $\ldots$ & $\ldots$ & $\ldots$ & $\ldots$ \\
4 & $\ldots$ & $\ldots$ & $\ldots$ & $\ldots$ & $\ldots$ \\
5 & $\ldots$ & $\ldots$ & $\ldots$ & $\ldots$ & $\ldots$ \\
\hline
\end{tabular}

\section{HASIL DAN PEMBAHASAN}

\section{Setelah peneliti melakukan} percobaan, didapatkan hasil sebagai berikut :

\section{HASIL}

Setelah peneliti melakukan uji coba alat, didapatkan data pengamatan seperti pada tabel 4
Tabel 4. Tabel pengamatan keadaan langit terhadap arus.

\begin{tabular}{cccc}
\hline No & $\begin{array}{c}\text { Keadaan } \\
\text { langit }\end{array}$ & $\begin{array}{c}\text { Rentang Arus yang } \\
\text { dihasilkan dari panel surya } \\
\text { (Amper) }\end{array}$ \\
\hline 1 & Mendung & 0.6 & 0.8 \\
& Cerah & & 1.9 \\
2 & berawan & 0.9 & 3.5 \\
\hline
\end{tabular}

Tabel 1 merupakan gambaran keadaan arus yang dihasilkan terhadap keadaan awan. Pada saat langit mendung, arus yang dihasilkan berkisar antara 0,6-0,8 ampere. Pada saat langit cerah berawan, arus yang dihasilkan dari panel surya berkisar antara 0,9-1,9 ampere. Pada saat keadaan cerah, arus yang dihasilkan oleh panel surya yaitu antara 2,0-3,5 ampere. Setelah itu peneliti melakukan pengamatan lama waktu pengecasan dari panel surya. Didapatkan data seperti pada tabel 5 dan tabel 6 , serta grafik yang dihasilkan pada gambar 4 dan gambar 5 .

Tabel 5. Data 1

\begin{tabular}{|c|c|c|c|c|c|}
\hline No & $\begin{array}{c}\text { Arus } \\
\text { tiap jam } \\
\text { (Amper) }\end{array}$ & Jam & $\begin{array}{l}\text { Presentase } \\
\text { Pengisian }\end{array}$ & Cuaca & $\begin{array}{c}\text { Tegangan } \\
\text { aki (Volt) }\end{array}$ \\
\hline 1 & 0.9 & $10: 00$ & $45 \%$ & $\begin{array}{c}\text { Cerah } \\
\text { berawan } \\
\text { Cerah }\end{array}$ & 11.5 \\
\hline 2 & 1 & 11:00 & $54 \%$ & $\begin{array}{c}\text { berawan } \\
\text { Cerah }\end{array}$ & 12.1 \\
\hline 3 & 1.1 & 12:00 & $61 \%$ & berawan & 12.3 \\
\hline 4 & 2 & 13:00 & $70 \%$ & Cerah & 12.6 \\
\hline 5 & 2 & $14: 00$ & $77 \%$ & Cerah & 12.9 \\
\hline
\end{tabular}

Pada tabel 5 merupakan data yang dihasilkan peneliti pada percobaan pertama. Keadaan langit yang didapatkan berupa cerah dan cerah berawan. Antara cerah dan cerah berawan, lebih banyak cerah berawan dibandingkan cerah. Arus yang dihasilkan oleh panel surya pun beragam. Akan tetapi apabila arus yang dihasilkan dirata-rata, maka arus rata-rata yang dihasilkan tiap jam yaitu sebesar 1,4 A. Besar rata-rata pengisian tiap jamnya yaitu $8 \%$ dan besar kenaikan tegangan baterai rata-rata yaitu 0,35 volt. 


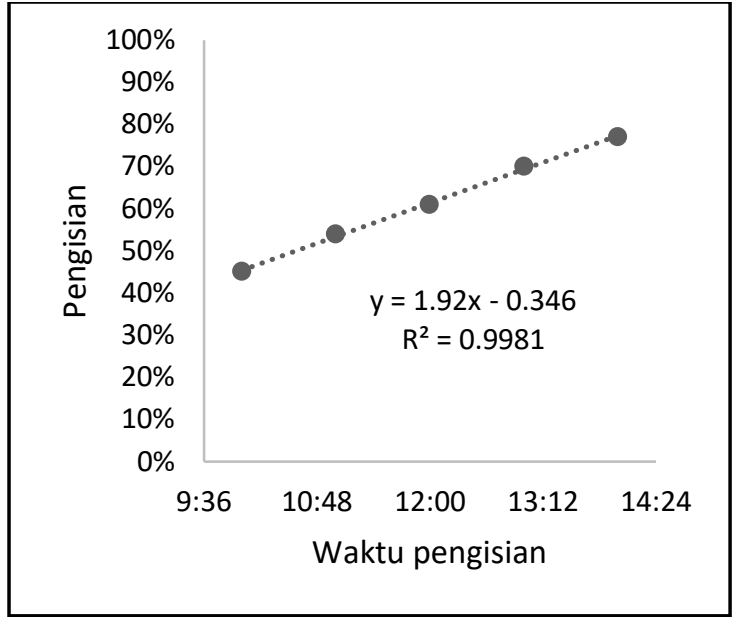

Gambar 4. Grafik hubungan antara presentasi Baterai dengan waktu pengisian data satu

Jika melihat hubungan waktu pengisian dan presentasi baterai, grafik yang dihasilkan merupakan grafik linier dengan kemiringan $y=1,92 x-0,346$ dengan $R^{2}=0,9981$.

Pada percobaan yang ke dua didapatkan data seperti pada tabel 6 .

Tabel 6. Data 2

\begin{tabular}{cccccc}
\hline No & $\begin{array}{c}\text { Arus } \\
\text { tiap jam } \\
\text { (Amper) }\end{array}$ & Jam & $\begin{array}{c}\text { Persentase } \\
\text { Pengisian }\end{array}$ & Cuaca & $\begin{array}{c}\text { Tegangan } \\
\text { aki (Volt) }\end{array}$ \\
\hline 1 & 2 & $8: 30$ & $60 \%$ & Cerah & 12.4 \\
2 & 1 & $9: 30$ & $78 \%$ & $\begin{array}{c}\text { cerah } \\
\text { berawan }\end{array}$ & 12.8 \\
3 & 2.6 & $10: 30$ & $86 \%$ & $\begin{array}{c}\text { Cerah } \\
\text { Cerah }\end{array}$ & 13.1 \\
4 & 1.5 & $11: 30$ & $91 \%$ & $\begin{array}{c}\text { Cerawan } \\
\text { berawan } \\
\text { cerah } \\
\text { berawan }\end{array}$ & 13.4 \\
5 & 1.1 & $12: 30$ & $95 \%$ & \multicolumn{3}{c}{ eran } \\
\hline
\end{tabular}

Pada percobaan kedua didapatkan data yang tidak jauh beda dengan percobaan pertama, yaitu keadaan langit yang didapatkan cerah dan cerah berawan. Akan tetapi arus rata-rata yang dihasilkan sedikit lebih besar yaitu sebesar 1,64 ampere. Akan tetapi kenaikan tegangan baterai rata-rata hanya sebesar 0,25 volt tiap jam. hal ini mungkin terjadi karena peneliti pada percobaan kedua tidak melakukan pengkondisian yang sama seperti pada percobaan pertama. Dengan besar arus yang dihasilkan, pengisian baterai rata-rata yaitu $9 \%$. Nilai ini sedikit lebih besar dari percobaan pertama dengan selisih $1 \%$.

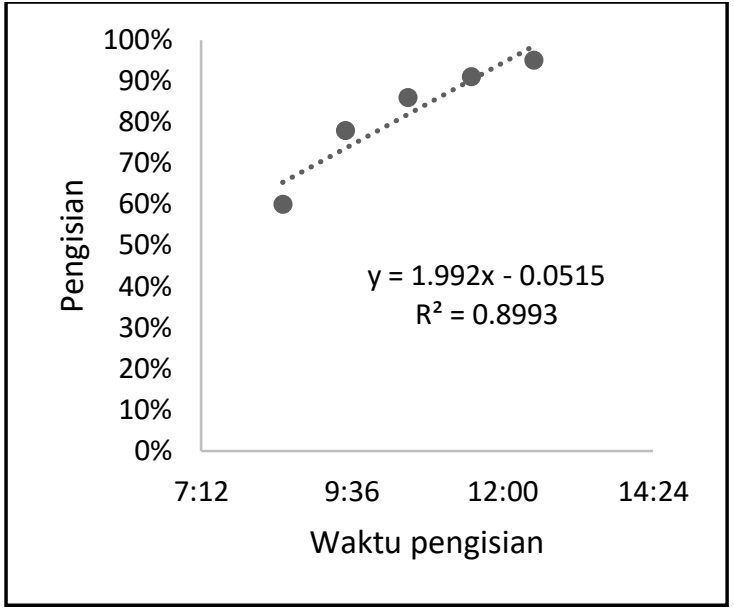

Gambar 5. Grafik hubungan antara presentase baterai dengan waktu pengisian data dua

Hubungan waktu pengisian dan presentase baterai berupa grafik linier dengan kemiringan $y=1,992-0,0515$. Sedangkan $R^{2}=0,8993$. Nilai $\mathrm{R}^{2}$ tersebut menunjukkan kurang baiknya kemiringan dari data karena data yang didapatkan kurang tepat di dalam garis lurus seperti yang dihasilkan pada data satu.

\section{PEMBAHASAN}

Telah dipaparkan data hasil penelitian yang telah dilakukan peneliti. Dari data yang didapatkan diketahui bahwa, arus listrik yang dihasilkan paling baik yaitu pada saat keadaan cerah tanpa dihalangi oleh awan. Besar arus maksimum yang dihasilkan mencapai 3,5 ampere. Persentase kenaikan rata-rata pengisian hanya mencapai $8 \%-9 \%$. Jika dalam waktu 1 jam persentase kenaikan hanya 8\%$9 \%$, maka waktu yang dibutuhkan untuk mencapai $100 \%$ adalah 12,5 jam dengan perhitungan sebagai berikut :

$$
\begin{aligned}
& \frac{1 \mathrm{jam}}{t_{\text {cas }}}=\frac{8 \%}{100 \%} \\
& t_{\text {cas }}=\frac{1.100 \%}{8 \%} \\
& t_{\text {cas }}=12,5 \mathrm{jam}
\end{aligned}
$$

Berarti, waktu yang dibutuhkan untuk melakukan pengecasan $\left(t_{c a s}\right)$ dari mulai pagi sampai dengan sore hari, dengan keadaan cahaya paling maksimal yaitu pada jam 09.00-16.00.

Jika diandaikan saat siang hari keadaan langit cerah, dengan besar arus yang dihasilkan yaitu 3,5 ampere, maka waktu yang dibutuhkan untuk melakukan pengecasan $\left(t_{c a s}\right)$ 
adalah hanya 5 jam saja dengan perhitungan sebagai berikut :

$$
\begin{gathered}
\frac{1,4 \mathrm{~A}}{3,5 \mathrm{~A}}=\frac{8 \%}{t_{\text {cas }}} \\
t_{\text {cas }}=\frac{3,5 \mathrm{~A} \cdot 8 \%}{1,4 \mathrm{~A}} \\
t_{\text {cas }}=20 \%
\end{gathered}
$$

Dari perhitungan dapat diketahui bahwa jika arus yang dihasilkan adalah 3,5 ampere, maka dalam waktu 1 jam dapat melakukan pengisian sebesar 20\%. Berarti untuk mencapai keadaan $100 \%$ hanya dibutuhkan 5 jam saja. Nilai ini berlaku pula untuk data yang ke dua, karena nilai arus yang didapatkan ratarata memiliki selisih nilai hampir sama yaitu 1,4 ampere dan 1,64 ampere.

Adapun kekurangan dan kelebihan pada penelitian ini yaitu panel surya yang peneliti gunakan hanya satu, akan lebih baik jika menggunakan dua buah panel surya 150 watt sehingga arus yang dihasilkan pun lebih besar. Keadaan langit yang tidak bisa dikontrol sehingga data yang didapatkan tidak sesuai harapan peneliti tetapi masih dalam kategori baik. Pada penelitian ini belum menggunakan sensor yang mengikuti arah sinar matahari. Menurut hasil penelitian Anwar, dkk (2016), menyatakan bahwa jika panel surya mampu bergerak mengikuti cahaya matahari, maka arus yang dihasilkan akan jauh lebih stabil dibandingkan dengan yang tidak.

\section{PENUTUP}

Dari penelitian yang telah dilakukan, dapat disimpulkan bahwa arus yang dihasilkan oleh cahaya matahari paling tinggi pada keadaan cerah. Dari data yang didapatkan arus rata-rata yang dihasilkan yaitu 1,4 ampere dan 1,64 ampere dengan keadaan langit cerah dan cerah berawan.

Saran untuk penelitian berikutnya adalah ketika ingin melakukan penelitian menggunakan cahaya matahari, ada baiknya melihat keadaan cuaca dari BMKG. Hal tersebut dilakukan untuk memastikan keadaan cuaca pada hari tersebut.

\section{UCAPAN TERIMA KASIH}

Peneliti mengucapkan banyak terimakasih kepada keluarga ku yang telah memberikan waktu kepada peneliti untuk menyelesaikan penelitian ini. Terimakasih pula kepada Universitas Muhammadiyah Metro yang telah mensuport peneliti. Terimakasih yang sebesar-besarnya kepada DRPM RISTEK DIKTI yang telah mendanai seluruh kegiatan dalam penelitian ini.

\section{DAFTAR PUSTAKA}

Anwar, d. (2016). Analisis Desain Sistem Pembangkit Listrik Tenaga Surya Kapasitas 50 WP. Jurnal Teknik UNDIP.

https://doi.org/10.14710/teknik.v37i2.9 011

Arsa, I. P. (2017). Pembangkit Listrik Tenaga Surya, Energi Bersih dan Murah (Studi Kasus Rumah Pariwisata Di Bali). Seminar Nasional Teknik Elektro Fakultas Teknik Universitas Negri Gorontalo. Gorontalo: Prosiding Seminar Nasional Teknik Elektro Fakultas Teknik Universitas Negri Gorontalo.

Fonash, S. J. (2010). Solar Cell Device Physics Secon Edition. USA: Academic press is an imprint of Elsevier.

Subandi \& Hani, S. (2015). Pembangkit Litrik Energi Matahari Sebagai Penggerak Pompa Air Dengan Menggunakan Solar Sel. Jurnal Teknologi Technoscientia, 7(2).

Jager, d. (2014). SOLAR ENERGY. Netherlands: Delft Univercity of Technology.

Perkasa, U. R. (2018). Jenis-jenis Panel Surya yang harus kamu Tahu. Diambil kembali dari https://www.solarcellsurya.com/jenispanel-surya/

Widodo, J. (2017). Perpres No 22 Tahun 2017 tentang Rencana Umum Energi 
Nasional. Jakarta: Sekretariat Kabinet

RI.

Dzulfikar, D., \& Broto, W. (2016). Optimalisasi

Pemanfaatan Energi Listrik Tenaga

Surya Skala Rumah Tangga. Prosiding

Seminar Nasional Fisika, 5.

https://doi.org/10.21009/0305020614 